


\title{
O PROJETO DE ESPACOS PÚBLICOS EM ÁREAS DE ASSENTAMENTO INFORMAL ${ }^{1}$
}

THE PROJECTS OF URBAN PUBLIC SPACES

IN INFORMAL AREAS

Clécio Magalhães do Vale ${ }^{2}$

Maria Elisa Baptista ${ }^{3}$

\section{Resumo}

O projeto de urbanização do Beco São Joaquim, na Vila Mãe dos Pobres, em Belo Horizonte, foi executado mediante convênio entre o Escritório de Integração do Departamento de Arquitetura e Urbanismo da PUC Minas e a Urbel, autarquia municipal responsável pela formulação e implantação das políticas urbanas em áreas de vilas e favelas. Constatou-se que, nessas áreas extremamente complexas, que são os assentamentos informais, o projeto de desenho urbano não consegue prever e orientar integralmente a obra. É preciso considerá-lo um plano aberto, com amplas maneiras de se concretizar. É necessário o acompanhamento permanente do processo de execução, de modo que a obra possa dar conta daquilo que projetistas e futuros usuários não conseguiram perceber ou equacionar no tempo de projeto.

Palavras-chave: Desenho urbano; Arquitetura pública; Áreas de risco.

\begin{abstract}
The urbanization design of the São Joaquim Alleyway, at the Vila Mãe dos Pobres, in Belo Horizonte, was run through a partnership between the Escritório de Integração do Departamento de Arquitetura e Urbanismo of PUC Minas and URBEL, local authority responsible for the formulation and implementation of urban policies in villages and slums. It was concluded that these highly complex areas, which are informal settlements, the urban design cannot fully predict and guide the work. It must be considered an open plan with ample ways to materialize. It is necessary a constant monitoring of the implementation process, so that the work can account what designers and future users failed to notice or equate at the project time.
\end{abstract}

Keywords: urban design, architecture public, risk areas 